\title{
Selection of stock: A Practical study on Nationalised Banks
}

\author{
${ }^{1}$.RadhakrishnaNayak, ${ }^{2}$. Kishor Salian \\ (M.COM, NET, ADCA)Faculty, Post Graduate Department, Saint Mary's Syrian College, Bramhavara. \\ Faculty, Department of Commerce,Saint Mary's Syrian College, Bramhavara
}

\begin{abstract}
Most people would agree that they want to make and have money, but very few people would agree to the level of risk they are willing to take on to make that money. Therefore, risk must be first issue an investor address when he is looking at choosing his investment.

India is a developing country. Traditionally there was limited investment avenues access for the people. With the development of an economy different investment alternatives came into existence. Share market investment placed in superior position among all. One can success here only when he is able to select right script in right entry time. Present paper aims at guide an investor in respect of selection of securities using different evaluation criteria respectively supported with practical study.

Keywords: Investment, Beta, CAPM, Return, Risk, Expected Rate of Return (ERR)
\end{abstract}

\section{Introduction:}

In finance, investment is the purchase of an asset or item with the hope that it will generate income or appreciate in the future and be sold in higher price. This is the opposite of trading or speculation, which are short term practice involving a much higher level of risk. Financial asset takes many forms and range from the ultra safe low return government bond to much higher risk, higher reward international stocks. In March 2013, Forbes Magazine had Warren Buffet ranked as number 2 in their Forbes Rank list. Buffet has advised in numerous articles and interviews that a good investment strategy is long term and choosing a the right asset to invest in due diligence.

Many new investor believe there is some secret strategy which will guarantee success, but unfortunately there is no such magic formula, and stock selection is just another important piece to help build portfolio. With wide array of investment solution available, it can be challenging to know which investment are best suited to market needs. To simplify the selection process, investor can choose stock on the basis of return analysis, risk analysis, Capital Asset Pricing Model, efficient frontier technique etc. Herea practical analysis has been done with an example of nationalized banks \& their present performance for five year on quarterly basis.

\section{Capital Asset Pricing Model:}

The Capital Asset Pricing Model provides a formula that calculate the expected return on a security based on its level of risk.

To understand the Capital asset pricing model, there must be an understanding of the risk on an investment. Individual securities carry a risk of depreciation which is a loss of investment to the investor. Some securities have more risk than others and with additional risk, an investor expect to realize a higher return on their investment.

The risk involved when evaluating a particular stock is accounted for in the Capital Asset Pricing Model formula with Beta. Specially regarding to the CAPM formula, beta is the measure of risk involved with investing in particular stock relation to the market. The beta of the market would be 1 . An individual security with a beta of 1.5 would be as proportionally riskier then the market and inversely, a beta of .5 would have less risk then the market.

\section{Risk Premium in the Capital Asset Pricing Model:}

The CAPM formula can be broken up into two components. The risk free rate of return and risk premium of the particular security. The risk free rate of return represented with gilt edged or government securities (3 month t-bill issued by government). Risk premium represents the composition which derived from the stock for having investment in market. In other word risk premium is the excess return for taking additional risk.

\section{Indian Banking Industry;}

The present Rs.64 trillion (US\$ 1.17 trillion) Indian banking industry is governed by the Banking Regulation Act, (1949) and is closely monitored by the Reserve Bank of India (RBI). RBI manages the country's money supply and foreign exchange and also serves as a bank for the government of India and for the country's commercial banks. As of now, public sector banks accounts for 70 per cent of Indian Banking Asset. 
Liberal policies, Government support and huge development in other economic segments have made the Indian banking industry more progressive and inclusive with regard to global banking standards.

According to an IBA-FICCI-BCG report, India's Gross Domestic Product (GDP) growth will make the Indian banking industry the third largest in the world by 2025.

\section{Factor Promoting Growth of Indian Banking Sector:}

- $\quad$ The banking sector highly correlated with the economy of the country. The GDP growth is estimated at 7.6 per cent for the financial year 2013, so the economy is expected to recover and be back on the growth track in financial year 2013. This will also result in the banking space witnessing a spurt growth in business next fiscal.

- Increasing disposable income and increasing exposure to range of their products, have led consumer towards a higher willingness to take credit, particularly, young customers.

- Increasing spread of mobile banking, which is expected to became the second largest channel for banking after ATM's, will accelerate growth of the sector.

- Financial inclusion program: currently, $41 \%$ of the adult populations don't have bank accounts, which indicate a large untapped market for banking player. Under the financial inclusion programme, RBI is trying to tap the untapped market and the growth potential in rural markets by volume growth for bankers.

This all factors strongly support the need to select the banking industry for investment appraisal.

\section{Objectives of present study:}

Modern world is highly competitive one, future is completely uncertain; in this situation predicting future is very difficult. Basically present paper deals with following objectives.

- To highlight on basic financial concept.

- To guide an investor in selection of security.

- To compare actual return with standard expected return, this is calculated using CAPM.

- To focus on the concept of efficient frontier.

\section{Source of Data:}

\section{Methodology:}

To understand the concept of different investment criteria with an practical example, nationalized banks from banking industry has been taken as proxy. The study is mainly based on secondary data. Nationalized banks \& their capital market performance for last five year recorded on the basis of each quarter end market price.

\section{Sample Data:}

The empirical study has been conducted in respect of nationalized banks. The study includes20 nationalized banks and their financial performance for last five year on the basis each quarter end market price.

\section{Tools of analysis:}

Present study is done with the help of actual average return, standard deviation, the beta concept,and expected return for CAPM, \% of variation between expected return \& actual return, Ranking, the concept of efficient frontier etc.

\section{Findings of the study;}

Investing is an intensely personal endeavor; no one strategy or style fits everyone. These resources will help you identify which type of investor you are and what may work best based upon your needs and goals. The key to successful investing is consistency. If you are buying shares of good businesses, that generate real profits, attractive returns on equity.

\section{An Evaluation On the basis Actual Average Return:}

Traditionally a person interested to maximize overall return and concept of risk was least bothered. A great investing strategy for most investor is being average. Investing in companies you are familiar with and understood is one of the keys to success in the stock market. 


\begin{tabular}{|c|c|c|c|c|c|c|c|}
\hline Serial & & & & & $\underline{\text { CAPM - expected }}$ & & \\
\hline No & Name of the Bank & Return & $\underline{S . D}$ & Beta & return & \% Variation & Ranking \\
\hline 1 & Allahabad Bank & 8 & 32.52 & 2.27 & 7.24 & 10.52 & 5 \\
\hline 2 & Andhra Bank & 3.95 & 27.27 & 1.8 & 6.16 & -35.90 & 13 \\
\hline 3 & Bank of Baroda & 6.79 & 25.21 & 0 & 2.04 & 232.84 & 2 \\
\hline 4 & Bank of India & 0.93 & 25.14 & 1.62 & 5.75 & -83.83 & 18 \\
\hline 5 & Bank of Maharashtra & 6.06 & 26.64 & 1.96 & 6.53 & -7.17 & 7 \\
\hline 6 & Canara Bank & 4.31 & 23.66 & 1.58 & 5.66 & -23.83 & 10 \\
\hline 7 & Central Bank of India & 9.61 & 45.88 & 0 & 2.04 & 371.08 & 1 \\
\hline 8 & Corporation Bank & 5.1 & 29.81 & 2.24 & 7.17 & -28.87 & 11 \\
\hline 9 & Dena Bank & 6.16 & 31.32 & 1.99 & 6.60 & -6.63 & 6 \\
\hline 10 & IDBI Bank & 5.53 & 35.83 & 2.83 & 8.52 & -35.10 & 12 \\
\hline 11 & Indian Bank & 2.14 & 26.3 & 1.73 & 6.00 & -64.34 & 16 \\
\hline 12 & Indian Overseas Bank & 3.31 & 28.81 & 2.17 & 7.01 & -52.78 & 15 \\
\hline 13 & Oriental Bank of c.. & 4.35 & 24.67 & 0.23 & 2.57 & 69.48 & 3 \\
\hline 14 & Punjab National Bank & 2.87 & 21.88 & 1.63 & 5.77 & -50.28 & 14 \\
\hline 15 & Punjab \& Sind Bank & -8.8 & 11.77 & 0.37 & 2.89 & -404.78 & 20 \\
\hline 16 & Syndicate Bank & 4.56 & 24.68 & 1.45 & 5.36 & -14.93 & 8 \\
\hline 17 & UCO Bank & 8.46 & 27.84 & 1.89 & 6.37 & 32.85 & 4 \\
\hline 18 & Union Bank of India & 1.6 & 24.82 & 1.52 & 5.52 & -71.02 & 17 \\
\hline 19 & United Bank of India & -2.15 & 27.24 & 0.77 & 3.80 & -156.53 & 19 \\
\hline \multirow[t]{3}{*}{20} & Vijaya Bank & 5.52 & 17.01 & 1.99 & 6.60 & -16.33 & 9 \\
\hline & NSE (Market Index) & 4.33 & & & & & \\
\hline & Risk Free Rate of Return & 2.04 & & & & & \\
\hline
\end{tabular}

In above table percentage of return shows average return of individual companies calculated considering their capital market performance in last five years tenure. Central Bank of India, UCO Bank and Allahabad Bank has yielded 9.61, 8 and 8.46 percentage of return respectively. If investor is just interested in return he can select above mentioned bank's script. This should be noted that Punjab \& Sind Bank, United Bank of India have listed negative return.

\section{An Evaluation On the basis Standard Deviation:}

Any rational investor, before investing his or her investible wealth in the stock, analyses the risk associated with the particular stock. The actual return he receives from a stock may vary from his expected return and the risk is expressed in term of variability of return. Investor in general would like to analyse the risk factor and thorough knowledge of the risk helps him to minimize risk associated with his investment.

In the case of nationalized banks Punjab \& Sind Bank, Vijaya Bank and Punjab National Bank's has 11.77, 17.01 and 21.88 percentage of variation in their expected return respectively. But at the same time Punjab and Sind Bank has gained negative return. Investor with risk sensitiveness can select Punjab National Bank andVijaya Bank to get return without much variation.

\section{The Concept of Beta:}

Betas describe the relationship between the stock's return and the index returns. The Beta coefficient, in terms of finance and investing, is a measure of a stock's (or portfolio's) volatility in relation to the rest of the market. Beta is calculated for individual companies using regression analysis. Beta value may be ranged from negative to positive value and different value represents different meaning.

- Beta < 0: Negative Beta - not likely.

- Beta $=0$ : Cash in the bank.

- Beta Between 0 and 1: Low-volatility

- $\quad$ Beta $=1$ : Matching the market.

- Beta > 1: More volatile than the market.

In present example it should be noted that all the banking script has got positive beta value, it indicates that there is a co-movement found between market and banking sector. Low beta indicates less response to market and denoted that less risky shares. Investor with less risk tolerance can select script of Central Bank of India, Bank of Baroda and Oriental Bank of Commerce since it shows less response to the market unexpected fluctuation. 
Person with medium risk expectation can hold shares of companies those which having beta nearer to 1. Here in this example Syndicate Bank and United Bank of India suits better. If an investor belonging for risk lover category can select high responsive shares like IDBI Bank and Allahabad Bank.

\section{Capital Asset Pricing Model (CAPM):}

As mentioned before capital asset pricing model is the indicator of minimum return to be expected to match the present level of risk. This includes both risk free return and risk premium.Here 1, 3, 7,13 and 17 numbered banks has yielded more return then minimum return required by this risk adjusted model. And remaining banking scripts still under performing in their capital market deal. In above table last column shows ranking on the basis of variation return.

\section{The Concept of efficient frontier:}

The risk and return of all banking companies shares plotted in risk-return space would be dominated by efficient stock. Out of available 20 banks some are more attractive than others. Among all stocks, the stock which offers the highest return at particular level of risk or lowest risk for particular level return is called efficient frontier.

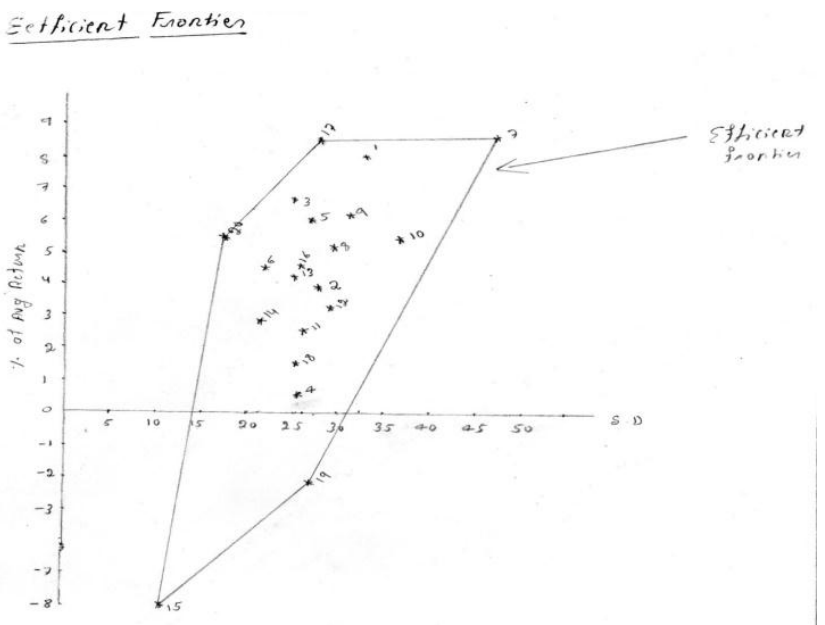

Above diagramical representation of risk-return space of banks has given frontier with possible choices. Point 17 i.e., UCO Bank and point 19 i.e., United Bank of India have same standard deviation but return vice UCO bank dominates. Likewise point 7 i.e., Central Bank of India attracts risk taker since it is having high return. If anyone wants to minimize loss to maximum extent can select point 20 i.e., Vijaya Bank.

Selection of security is completely depending upon utility factor of individual. Among dominating points, one can select any security or combination security to optimize investment objective.

\section{Limitation of the study:}

- Past performance is no guarantee of future result: all most all investment literature warn you that past performance is no guarantee of future result.

- Do not put all eggs in one basket: unsystematic risk can be avoided by professional diversification, but portfolio concept has not been considered in evaluation.

- Capital market doesn't mean that group of nationalized banks: present study is just done with nationalized bank. It is not possible to analyse entire banking sector with a group of nationalized bank. And only banking sector can not judge entire share market.

- Study is just limited for last five year that too quarter end share market price comparison. But share market can see daily surprising direction.

\section{Conclusion:}

All the financial dailies and investment related magazines publish the stock market news. Separate News Bulletins are issued by BSE, NSE and OTCEI providing information regarding the change takes place in the stock market. SEBI news letter gives the changes in rules and regulations regarding the activities of the stock market. Reserve Bank of India Bulletin also carries the information about the stock market. Investor who wants to success in share market investment must have knowledge, time \& patience to wait. 


\section{Reference:}

[1]. Khan, M Y, Financial Service, Tata McGraw-Hill Publishing Co., New Delhi, 2007.

[2]. Pndian, Punithavathy, Security Analysis and Portfolio Management, Vikas Publishing House Private ltd, Noida,2011.

[3]. http://money.rediff.com/

[4]. http://profit.ndtv.com/

[5]. http://en.wikipedia.org/wiki/List_of_banks_in_India 